\title{
Biopellet Production from the Wastes of Palm Oil Plantation and Processing Plant Through Various Pretreatment Processes: A Review
}

\author{
Diah Indriani Widiputri*, Fernanda Ayuyasmin, Evita Herawati Legowo
}

Faculty of Life Sciences and Technology, Swiss German University, Tangerang, Indonesia

${ }^{*}$ Corresponding author. Email: diah.widiputri@sgu.ac.id

\begin{abstract}
Indonesia as one of the world's largest palm oil producers is facing one significant problem with the amount of wastes they are producing from different stages in palm oil processing, which are consisted of the oil palm trunk (OPT), oil palm frond (OPF), empty fruit bunches (EFB), mesocarp fibre (MF) and oil palm shells (OPS). Hence, there is a need to explore the potential utilization of biomass waste coming from palm oil production as an alternative energy source, e.g. in the form of biopellets. This work was aimed to perform a literature review of various available biopellet processing techniques, which provides a summary and systematic comparison between different methods to utilize the abundant biomass waste produced by palm oil plantations and processing plants. The quality parameters of biopellet compared in this study were the moisture content, ash content, calorific value, fixed carbon content and the mechanical durability. The results of this review showed that the acid pretreatment is by far the most successful pretreatment, among others. However, a combination between various pretreatment methods should be explored to optimize the quality parameters of produced biopellets. The commercial utilization of oil palm waste-based biopellets will overcome both the national renewable energy demand problem and environmental issue.
\end{abstract}

Keywords: Alternative energy, Biomass, Biopellet, Palm oil waste, Waste to energy.

\section{INTRODUCTION}

World energy consumption has been increasing from year to year with fossil fuels as the primary energy source. Oil consumption still has a major role to play in the energy mix, representing around $33.1 \%$, with a growth of $0.9 \%$ in 2019 , followed by coal with a share of $27 \%$. Beside the fact that fossil fuel is depleting, carbon emission resulting from the burning of fossil fuels is another important issue to be considered. However, the world's carbon emissions from energy use grew by $0.5 \%$ in 2019, which is much less than the 10-year average growth of $1.1 \%$ per year. This can be seen as a result of increasing displacement of coal from the energy mix by renewables and natural gas [1].

Renewable energy (including biofuels but excluding hydro) has shown the largest increase for any source of energy in 2019 energy consumption, as much as 3.2 EJ (Exajoule) showing a growth of $12.1 \%$. Wind provided the biggest contribution in this growth followed by solar. The rest of the share was provided by among others the biomass-based energy source such as biofuels and biomass pellets. Even though it is currently not the biggest contributor in the growth, exploration to use biomass as a source of alternative energy must be broadened.

Indonesia's biomass potential is very large and promising, estimated to be approximately $50 \mathrm{GWe}$. Indonesia's national annual production of biomass is approximately 140 million tons, and when fully utilized can resolve both the country's waste and energy problem [2]. However, according to Indonesia Energy Transition Outlook (IETO) 2021, the installed capacity addition until Q3 2020 of biomass in Indonesia placed third on renewable energy sources after hydropower and solar, with only 13.7 MW [3]. This shows that biomass as a a source of alternative energy is still underutilized.

One of the most abundant biomass sources in Indonesia can be found in palm oil plantations and oil palm mills. As one of the world's largest palm oil producers, Indonesia is facing a significant problem with the amount of wastes they are producing. 
Table 1 Biopellets' quality parameters standards

\begin{tabular}{l|c|c|c|c}
\hline Standards & Moisture Content (\%) & \multirow{2}{*}{ Ash Content (\%) } & \multicolumn{2}{|c}{ Calorific Value } \\
\cline { 3 - 5 } & & & $\mathbf{C a l} / \mathbf{g}$ & $\mathbf{M J} / \mathbf{k g}$ \\
\hline SNI 8021:2014 & $<12$ & $<1.5$ & $>4,000$ & $>16.74$ \\
\hline Austrian standard ONORM M 7135 & $<10$ & $<0.5$ & $>4,302$ & $>17.99$ \\
\hline German standard DIN 51731 & $<12$ & $<1.5$ & $3,705-4,661$ & $15.5-19.5$ \\
\hline Swedish standard SS 187120 & $<10$ & $<1.5$ & $>4,039$ & $>16.89$ \\
\hline Italian standard CTI-R04/05 & $\leq 10$ & $<1.5$ & $>4,039$ & $>16.89$ \\
\hline French ITEBE & $<10$ & $<10$ & $>4,052$ & $>16.95$ \\
\hline
\end{tabular}

The palm oil plantation produces two main types of solid wastes, which are the oil palm trunk (OPT) and oil palm frond (OPF) [4]. In the next stage, the extraction of crude palm oil (CPO) from the fresh fruit bunches results among others in solid wastes called the empty fruit bunches (EFB), mesocarp fiber (MF) and oil palm shells (OPS). During the refinery process, other wastes are resulting depending on different selected processing pathways. A national oil palm waste projection has been made for the amount of EFB and OPF alone, predicting that in the year 2030 the total amount of these wastes can add up to around 183 thousands of tons [5].

Biopellets can be produced from most of the abovementioned wastes. Conversion of biomass can be categorized into several processes including densification, carbonization, gasification, anaerobic digestion, and pyrolysis. Densification by using pellets is one of the most common options that has been used to increase the value of agricultural and biological materials. In order to achieve a good quality of biopellet, the composition of biopellet must be within the range of $6.85-7.45 \%$ moisture content, $1.7-1.9 \%$ ash content and having a calorific value of $3,814-4,724 \mathrm{cal} / \mathrm{g}$ [6]. The biopellets' quality parameters are regulated by different standards worldwide, as listed in Table 1.

With the potential benefits that can be yielded through application of the wastes from oil palm plantations and mill into biopellets, there has been a wide range of research conducted in this area. Different techniques and process conditions have been studied, using different types of oil palm wastes, yielding different quality and quantity of biomass pellet produced. Hence, in this research, a study to compile and compare different processes that have been developed to produce biopellets from palm oil wastes was made, with the purpose to provide the readers with information about current development of the process.

\section{BIOPELLET FROM CRUDE PALM OIL WASTES}

The first part of this review studied the production of biopellet from two main palm oil wastes, namely the empty fruit bunches (EFB) and the oil palm trunk (OPT). The EFB is obtained as a waste of palm oil mill, whereas
OPT is mainly collected as a waste during harvesting in the plantation. The production of biopellet commonly involves physical pre-treatment processes such as washing, size reduction and drying, and in some cases will require an addition of a binder or binding agent that will make the biopellet be more compact and firmer.

\subsection{Biopellet Production from Empty Fruit Bunches (EFB)}

The suitability of EFB for the production of biopellet, more specifically the EFB obtained as biomass waste from a palm oil plantation in North Sumatera, Indonesia, was investigated using the European standard for quality testing, including ISO 16559 (2014), ISO 17225-6 (2014) and ISO 17225-1 (2014) about solid biofuels [7]. The parameter testing on the EFB as the feedstock was conducted to study the basic chemistry parameters, energy potential and elementary compositions, with results listed in Table 2 . The obtained results have shown overall satisfactory values in meeting the mandatory technical standards to be used for solid biofuel production and are considered to be appropriate for production in commercial scale. As for the produced biopellets through densification process, a series of testing were required to be done to ensure strength and damage resistance of the pellets; these are the mechanical analysis (including density, mechanical durability and compressive strength) and microscopic analysis by means of Scanning Electron Microscopy (SEM).

Table 2 EFB characteristics on wet and dry basis [7].

\begin{tabular}{lccc}
\hline \multirow{2}{*}{ Indicator } & \multicolumn{2}{c}{ EFB } & European \\
\cline { 2 - 3 } & In w.b. & In d.b. & \\
Standard \\
\hline $\mathrm{M}_{\mathrm{c}}(\%)$ & 7.07 & - & $\leq 15$ \\
\hline $\mathrm{A}_{\mathrm{c}}(\%)$ & 9.41 & 10.12 & $\leq 10$ \\
\hline $\mathrm{GCV}(\mathrm{MJ} / \mathrm{kg})$ & 16.32 & 17.56 & - \\
\hline $\mathrm{NCV}(\mathrm{MJ} / \mathrm{kg})$ & 15.06 & 16.39 & $\geq 14.5$ \\
\hline $\mathrm{C}(\%)$ & 42.54 & 45.78 & - \\
\hline $\mathrm{H}(\%)$ & 5.80 & 5.39 & - \\
\hline $\mathrm{N}(\%)$ & 0.75 & 0.81 & $\leq 2.0$ \\
\hline $\mathrm{S}(\%)$ & 0.13 & 0.14 & $\leq 0.3$ \\
\hline $\mathrm{O}(\%)$ & - & 37.76 & - \\
\hline
\end{tabular}

$\overline{M_{c}: \text { moisture content, } A_{c}: \text { ash content, } G C V: \text { gross calorific value }}$ $N C V$ : net calorific value, $C$ : carbon content, $H$ : hydrogen content, $N$ : nitrogen content, $S$ : sulphur content, $O$ : oxygen content 
Table 3 Quality of biopellets produced from EFB using various pretreatment methods [8-11]

\begin{tabular}{|c|c|c|c|c|c|c|c|c|}
\hline Pretreatment method & Variations & $\begin{array}{l}\mathbf{M}_{\mathbf{c}} \\
(\%)\end{array}$ & $\begin{array}{c}A_{c} \\
(\%)\end{array}$ & $\begin{array}{c}\text { Volatile } \\
\text { matter }(\%)\end{array}$ & $\begin{array}{l}\text { Fixed } \\
\mathrm{C}(\%)\end{array}$ & $\begin{array}{c}\text { Mechanical } \\
\text { Test }\end{array}$ & $\begin{array}{c}\text { Cal. Value } \\
\text { (cal/g) }\end{array}$ & $\begin{array}{c}\text { Cal. Value } \\
(\mathrm{MJ} / \mathrm{kg})\end{array}$ \\
\hline \multirow{3}{*}{$\begin{array}{l}\text { Combined feedstock } \\
\text { with other types of } \\
\text { biomass [8] }\end{array}$} & $\begin{array}{l}\text { Biopellet from } \\
100 \% \text { TW }\end{array}$ & 8.69 & 4.19 & 74.78 & 21.03 & $99.93 *$ & $4,156.31$ & 17.39 \\
\hline & $\begin{array}{l}\text { Biopellet from } \\
100 \% \text { EFB }\end{array}$ & 9.58 & 0.86 & 83.76 & 15.39 & $99.68^{*}$ & 4,001 & 16.74 \\
\hline & $\begin{array}{l}\text { Biopellet from } \\
50 \% \text { TW }+50 \% \\
\text { EFB }\end{array}$ & 9.06 & 2.46 & 79.32 & 18.21 & $99.75^{*}$ & 4,0607 & 16.99 \\
\hline \multirow{8}{*}{$\begin{array}{l}\text { Mixing with PVAC } \\
\text { and Tapioca as } \\
\text { binding agents [10] }\end{array}$} & PVAC 3\% & 0.06 & 7.30 & 72.75 & 19.89 & $1.18 * *$ & 4,046 & 16.93 \\
\hline & PVAC 5\% & 1.20 & 7.52 & 71.12 & 20.17 & $1.22 * *$ & 4,098 & 17.15 \\
\hline & PVAC 7\% & 1.32 & 7.59 & 70.62 & 20.28 & $1.68 * *$ & 4,119 & 17.23 \\
\hline & PVAC $10 \%$ & 1.87 & 8.21 & 69.96 & 20.26 & $1.71 * *$ & 4,221 & 17.66 \\
\hline & Tapioca 3\% & 0.16 & 7.72 & 73.12 & 19.01 & $0.45 * *$ & 4,118 & 17.23 \\
\hline & Tapioca 5\% & 0.46 & 7.51 & 72.82 & 19.11 & $0.86^{* *}$ & 4,128 & 17.27 \\
\hline & Tapioca 7\% & 0.50 & 7.56 & 72.65 & 19.82 & $0.95 * *$ & 4,134 & 17.30 \\
\hline & Tapioca $10 \%$ & 0.90 & 7.36 & 72.24 & 20.40 & $1.20 * *$ & 4,206 & 17.60 \\
\hline $\begin{array}{l}\text { Mixing with starch } \\
\text { solution as binding } \\
\text { agent and variations of } \\
\text { EFB particle size [11] }\end{array}$ & $\begin{array}{l}50 \%-\mathrm{w} / \mathrm{v} \text { starch } \\
\text { solution and } \\
\text { EFB particle } \\
\text { size of } 20 \mathrm{mesh}\end{array}$ & 8.75 & 8.73 & 75.46 & n.a. & n.a. & $4,151.67$ & 17.37 \\
\hline
\end{tabular}

Mechanical analysis of the produced biopellet fuel has shown outstanding results: Volume density is $1,440.01 \mathrm{~kg} \cdot \mathrm{m}-3$ and the mechanical durability DU is 97.4\% (according to ISO 17831-1 (2015) this should be $\geqslant 96 \%$ ). These results indicated that EFB could go through the densification process and make high quality biopellet fuel. As for the produced biopellets through densification process, a series of testing were required to be done to ensure strength and damage resistance of the pellets; these are the mechanical analysis (including density, mechanical durability and compressive strength) and microscopic analysis by means of Scanning Electron Microscopy (SEM). Mechanical analysis of the produced biopellet fuel has shown outstanding results: Volume density is $1,440.01 \mathrm{~kg} \cdot \mathrm{m}-3$ and the mechanical durability DU is $97.4 \%$ (according to ISO 17831-1 (2015) this should be $\geqslant 96 \%$ ). These results indicated that EFB could go through the densification process and make high quality biopellet fuel.

Strong bonds within the internal structures of produced biopellet samples was observed in the microscopic analysis, which indicated high-quality densified biofuel. In general, EFB can be concluded to be a suitable and sustainable feedstock for use in biopellet production [7]. However, two of the values from above results do not meet the Indonesian national standard (SNI 8021:2014), which states that the maximum ash content of commercial biopellet is $1.5 \%$ and the minimum calorific value is $4,000 \mathrm{cal} / \mathrm{g} \approx 16.736 \mathrm{MJ} / \mathrm{kg}$. Hence, in order to fulfil these requirements, for the use of EFB as the feedstock for biopellet production in Indonesia, additional treatment to reduce the ash content and increase its calorific value is required.
One of the possible alternatives to improve quality of biopellet is by combining the feedstock with other types of biomasses. There have been several efforts made to combine the use of EFB with other materials, such as with tea waste from Malaysia [8]. This study was conducted with the purpose of maximizing the utilization of local biomass wastes, since the amount of tea waste is also quite abundant in Malaysia and has been proven to have good calorific value $( \pm 16.19 \mathrm{MJ} / \mathrm{kg})$ [9]. The effect on the pellet properties of mixing tea waste (TW) and oil palm empty fruit bunches (EFB) fibres was investigated. Properties of biomass fuel pellets including moisture content, density, calorific value, proximate matter, and durability were characterized and recorded in this research as summarized in Table 3.

The biopellet made by combining TW and EFB in 1:1 ratio by weight showed satisfactory results in terms of moisture content $(9.06 \%)$, gross calorific value (16.99 $\mathrm{MJ} / \mathrm{kg}$ ), and ash content $(2.46 \%)$. The durability test shows a DU index of $99.75 \%$, which is an excellent result in mechanical testing. From this research it can be seen that combining EFB with other potential feedstock would offer a promising way to improve biopellet quality.

Another alternative way that has been explored in previous researches to improve biopellet quality is by using more variation of physical pre-treatment and through the introduction of different types of binding agent. Aditya in his research [10] applied 5 stages of pretreatments, which included shredding, chopping, drying, grinding, and sieving prior to the manufacturing process. An additional process would be the mixing between the feedstock and binder. The binder used was varied between tapioca starch and polyvinyl acetate (PVAC) adhesive. 
This research also tested several parameters including density, mechanical strength, moisture content, ash content, fixed carbon, calorific value, and combustion rate. The results of this research are tabulated and compared to previously discussed research in Table 3. It can be seen that the variation of binding agent between PVAC and tapioca starch affected several parameters being tested. The pellet using PVAC as a binder showed overall better performance in the mechanical testing and gave higher compressive strength compared to pellets made using tapioca starch. The average moisture content of pellets with PVAC was on average higher $(1.1 \%)$ than those using tapioca (average of $0.505 \%$ ). However, the ash content, volatile matter content, and calorific value are not highly affected by the variation of binding agent between the two, nevertheless a trend can be observed in the calorific value results, that with increasing amount of binding agent the overall calorific value of the pellet increased. The highest calorific value in this research was found by mixing binding agent as much as $10 \%$ by weight of the pellet weight and showed a value of around $4,200 \mathrm{cal} / \mathrm{g}$ or equal to $17.57 \mathrm{MJ} / \mathrm{kg}$ for both $\mathrm{PVAC}$ and tapioca, which is by far the highest result discussed up to this point.

The use of starch (amylum) as binding agent in the production of EFB-pellets has also been researched [11]. To be used as binder, as much as $20 \mathrm{~g}$ of starch is dissolved with aquadest in a $100 \mathrm{ml}$ beaker. The mixture is stirred until completely mixed, then heated to $40^{\circ} \mathrm{C}$ until the mixture starts to thicken, then cooled down. The thickness of this mixture is varied further, using $30 \mathrm{~g}, 40$ $\mathrm{g}$ and $50 \mathrm{~g}$ of starch with the same procedure, to make starch solutions with compositions of $20 \%, 30 \%, 40 \%$ and $50 \%-w / v$ to be used in this experiment. The preparation of EFB as the feedstock was done using an automatic chopper, followed by a sieving using mesh 6 , 10 and 20.

Only the biopellet made using 50\%-w/v starch solution and EFB with size of 20 mesh, with a ratio of 60:40 (g EFB/ml starch solution) showed satisfactory results that met most of the criteria set by SNI 8021: 2014. Only the ash content and density are still out of the required value range. The ash content should be at a maximum value of $1.5 \%$ whereas density must not be bigger than $0.8 \mathrm{~g} / \mathrm{cm} 3$. The specification of this pellet is also shown in Table 3.

\subsection{Biopellet Production from Oil Palm Trunk (OPT)}

Another type of biomass waste from oil palm trees and is very abundant in its amount is the oil palm trunk (OPT) or stem. This is one part of the palm tree that is left as a waste in oil palm plantation, after the fruit bunches are harvested to be used in oil extraction in the mill. There is limited utilization of this trunk because unlike hardwood, it has a characteristic to be more fibrous. In this part of the literature review, research that has explored the utilization of OPT as a feedstock for biopellet production is discussed.

A research performed by Wistara [12] used OPT or oil palm stems to produce biopellet from the meristem part of 25 years old OPT, having various compositions of its bark $(0,10$, and $30 \%$ of the pellet total weight). The preparation of the stem was done through several size reduction processes to form a powder, which was then sieved by 40-60 mesh and 20-40 mesh. The finer powder having size distribution of 40-60 mesh is used for analysis purpose of the stem chemical compositions (Table 4), whereas the powder in the size range 20-40 mesh is used for biopellet production.

Table 4 Chemical composition of oil palm stem and bark [12].

\begin{tabular}{lcccc}
\hline $\begin{array}{c}\text { Chemical } \\
\text { component }\end{array}$ & $\begin{array}{c}\text { Bottom } \\
(\mathbf{\%})\end{array}$ & $\begin{array}{c}\text { Middle } \\
(\mathbf{\%})\end{array}$ & $\begin{array}{c}\text { Upper } \\
(\mathbf{\%})\end{array}$ & $\begin{array}{c}\text { Bark } \\
(\mathbf{\%})\end{array}$ \\
\hline Holocellulose & 72.92 & 73.85 & 72.41 & 64.98 \\
\hline Hemicellulose & 22.55 & 23.78 & 18.46 & 15.80 \\
\hline$\alpha$-cellulose & 50.37 & 50.07 & 53.95 & 49.18 \\
\hline Lignin & 25.78 & 24.73 & 21.56 & 33.61 \\
\hline Extractives & 8.39 & 9.25 & 7.63 & 9.22 \\
\hline Ash & 2.52 & 2.52 & 3.16 & 6.05 \\
\hline
\end{tabular}

The manufacturing of biopellets in this research was performed through densification at a pressure of 10.3 $\mathrm{MPa}$. Besides the bark contents, the densification temperature was also varied $\left(130,160\right.$ and $\left.190^{\circ} \mathrm{C}\right)$. The durability of the produced pellets through these variations was tested with the results shown in Figure 1. The suitability of EFB for the production of biopellet, more specifically the EFB obtained as biomass waste from a palm oil plantation in North Sumatera, Indonesia.

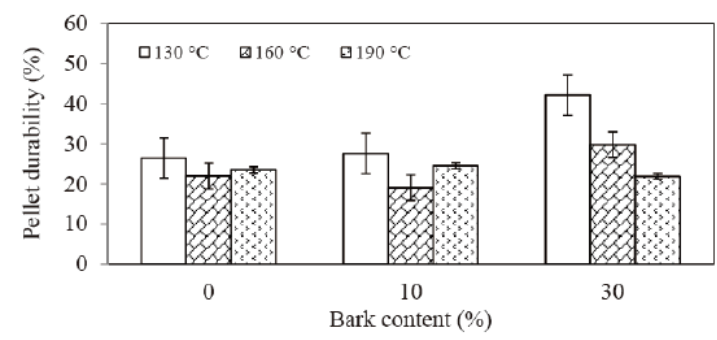

Figure 1 Effect of bark composition and densification temperature on OPT pellet's durability [12].

Figure 1 shows the effect of bark composition and densification temperature on the pellet durability DU index (\%). As can be seen, the overall DU index is very low $(\leqslant 50 \%$ ), which is not anywhere near the standardized value set by DIN EN 14961-2 A2 standard, requiring a minimum value of $97.5 \%$. The increase of bark content in the pellet resulted in higher DU, however the increase of densification temperature has an adverse effect on DU. 
Table 5 Quality of biopellets produced from OPT using various pretreatment methods [12-14]

\begin{tabular}{|c|c|c|c|c|c|c|c|}
\hline Pretreatment method & Variations & $\begin{array}{l}\mathbf{M}_{\mathbf{c}} \\
(\%)\end{array}$ & $\begin{array}{c}\mathbf{A}_{\mathbf{c}} \\
(\%)\end{array}$ & $\begin{array}{c}\text { Fly Ash } \\
(\%)\end{array}$ & $\begin{array}{c}\text { Fixed C } \\
(\%)\end{array}$ & $\begin{array}{c}\text { Cal. Value } \\
\text { (cal/g) }\end{array}$ & $\begin{array}{c}\text { Cal. Value } \\
\text { (MJ/kg) }\end{array}$ \\
\hline \multirow{3}{*}{$\begin{array}{l}\text { Heating of OPT at different } \\
\text { temperature between 130- } \\
190^{\circ} \mathrm{C}[12]\end{array}$} & $0 \%$-w bark & $8.45^{*}$ & $2.97 *$ & n.a. & $21.03 *$ & $4,273^{*}$ & $17.89 *$ \\
\hline & $10 \%$-w bark & $8.54 *$ & $2.99 *$ & n.a. & $15.39 *$ & $4,316^{*}$ & $18.07 *$ \\
\hline & $30 \%-\mathrm{w}$ bark & $9.24 *$ & $3.41 *$ & n.a. & $18.21 *$ & $4,339 *$ & $18.17 *$ \\
\hline \multirow{8}{*}{$\begin{array}{l}\text { Mixing with tapioca and } \\
\text { sago as binders and } \\
\text { reduction of OPT powder } \\
\text { size [13] }\end{array}$} & Tapioca; 10-mesh & 6.75 & 4.69 & 73.71 & 21.6 & $4,451.57$ & 18.63 \\
\hline & Sago; 10-mesh & 6.56 & 8.51 & 77.46 & 14.02 & $4,228.00$ & 17.69 \\
\hline & Tapioca; 20-mesh & 5.86 & 6.03 & 72.62 & 21.35 & $3,990.33$ & 16.69 \\
\hline & Sago; 20-mesh & 6.64 & 6.54 & 76.99 & 16.70 & $3,854.67$ & 16.13 \\
\hline & Tapioca; 40-mesh & 5.27 & 7.96 & 76.54 & 15.50 & $4,147.33$ & 17.35 \\
\hline & Sago; 40-mesh & 5.85 & 8.58 & 73.57 & 17.85 & $3,719.67$ & 15.56 \\
\hline & Tapioca; 60-mesh & 6.28 & 8.73 & 73.98 & 17.29 & $3,799.00$ & 15.89 \\
\hline & Sago; 60-mesh & 6.60 & 5.79 & 75.64 & 18.57 & $4,047.33$ & 16.93 \\
\hline \multirow{8}{*}{$\begin{array}{l}\text { Combined feedstock laban } \\
\text { wood charcoal with various } \\
\text { weight ratio between } \\
\text { OPT:Charcoal [14] }\end{array}$} & Tapioca; $25: 75$ & 6.75 & 4.69 & 73.71 & 59.97 & $4,451.57$ & 18.63 \\
\hline & Sago; 25:75 & 6.56 & 8.51 & 77.46 & 42.24 & $4,228.00$ & 17.69 \\
\hline & Tapioca; 50:50 & 5.86 & 6.03 & 72.62 & 45.42 & $3,990.33$ & 16.69 \\
\hline & Sago; 50:50 & 6.64 & 6.54 & 76.99 & 42.14 & $3,854.67$ & 16.13 \\
\hline & Tapioca; $75: 25$ & 5.27 & 7.96 & 76.54 & 32.33 & $4,147.33$ & 17.35 \\
\hline & Sago; 75:25 & 5.85 & 8.58 & 73.57 & 36.93 & $3,719.67$ & 15.56 \\
\hline & Tapioca; 100:0 & 6.28 & 8.73 & 73.98 & 26.45 & $3,799.00$ & 15.89 \\
\hline & Sago; 100:0 & 6.60 & 5.79 & 75.64 & 39.49 & $4,047.33$ & 16.93 \\
\hline
\end{tabular}

*Average value obtained in temperature range $130-190^{\circ} \mathrm{C}$

This might occur due to the lignin content in the bark that contributes to the particle bonding, which has been reported to decompose at a temperature around $140^{\circ} \mathrm{C}$. When this happens, it is possible that the binding capability of lignin decreases as well. The other important characteristics of the OPT based pellet are shown in Table 5, which are moisture content, ash content and the calorific value.

Scanning Electron Microscopy (SEM) analysis conducted in this research showed that OPT pellets have interparticle interlocking even in high bark composition, indicating that many gaps between particles are present. This confirms the low durability of the pellets discussed earlier. A higher densification pressure (100-150 MPa) could be a means to increase the durability. The effect of varying the OPT powder size as a feedstock for biopellet was observed in another research by Zulfian, et al [13]. In this research, OPT were reduced in its size to $10-60$ mesh. The binder types used were varied between tapioca and sago starch in the amount of $5 \%$ of pellet total weight. As in other researches, the moisture content, ash content and calorific value of the resulting pellet were studied according to SNI 8021: 2014. In addition to those parameters, the fly ash and the fixed carbon were also analysed.

The result summarized in Table 5 shows that the type of binder and the size of the powder did not significantly affect the value of moisture content, ash content, levels of flying matter and fixed carbon, but had a very significant effect on the calorific value. From all the variations performed in this research, the best result was shown when using OPT powder in the size of 10 mesh with tapioca starch as the binder. Even though the ash content is still not in the range requested by SNI 8021 : 2014 (must be $\leqslant 1.5 \%$ ), other requirements are fulfilled by this variation.

An extension of this work was done through the addition of laban wood charcoal into the OPT powder to be used as feedstock for pellet manufacturing [14]. The composition ratio by weight between the OPT powder 40 mesh in size and the laban wood charcoal was varied to be $25: 75,50: 50$ and 75:25, whereas the binders used in the manufacturing process of the biopellet varied between tapioca and sago starch. The resulting pellet characteristics are also shown in Table 5 and compared to the previously discussed research. All of the variations also show a decrease of ash content, approaching the required maximum value of $1.5 \%$. The use of sago as binder in all 25:75, 50:50 and 75:25 ratio between OPT and charcoal, and tapioca with 75:25 ratio, showed ash content value lower than $1.5 \%$.

It can be concluded that the change in feedstock ratio also influences pellet characteristics. The results of this study show that the oil palm trunk with the addition of charcoal can meet the ash content standard, which has not been fulfilled in any other research discussed in this work by far.

\section{BIOPELLET PRODUCTION WITH CHEMICAL PRETREATMENT PROCESS}

\subsection{Biopellet Production with Acid Pretreatment}


Table 6 Biopellet characteristics made from chemically pretreated OPT using sulphuric acid [15]

\begin{tabular}{|c|c|c|c|c|c|c|}
\hline $\begin{array}{c}\text { Bark composition } \\
(\%-w t)\end{array}$ & $\begin{array}{c}\mathrm{H}_{2} \mathrm{SO}_{4} \\
(\%-\mathrm{w} / \mathrm{v})\end{array}$ & $\begin{array}{c}\text { Calorific Value } \\
\text { (cal/g) }\end{array}$ & $\begin{array}{r}\text { Density } \\
\left(\mathrm{g} / \mathrm{cm}^{3}\right)\end{array}$ & $\begin{array}{c}\mathrm{H}_{2} \mathrm{SO}_{4} \\
(\%-\mathrm{w} / \mathrm{v})\end{array}$ & $\operatorname{Mc}(\%)$ & $\operatorname{Ac}(\%)$ \\
\hline \multirow{6}{*}{ 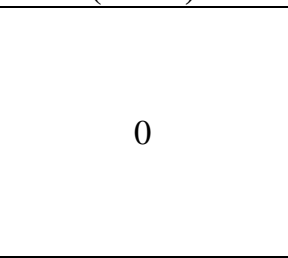 } & \multirow[t]{3}{*}{1} & \multirow[t]{3}{*}{ n.a } & \multirow{3}{*}{1.28} & 20 mesh & 5.50 & 1.20 \\
\hline & & & & 40 mesh & 4.00 & 1.30 \\
\hline & & & & 60 mesh & 3.80 & 1.40 \\
\hline & \multirow[t]{3}{*}{5} & \multirow[t]{3}{*}{4,480} & \multirow{3}{*}{1.30} & 20 mesh & 4.00 & 1.20 \\
\hline & & & & 40 mesh & 6.10 & 1.35 \\
\hline & & & & 60 mesh & 4.80 & 1.40 \\
\hline \multirow{6}{*}{10} & \multirow[t]{3}{*}{1} & \multirow[t]{3}{*}{ n.a. } & \multirow[t]{3}{*}{1.23} & 20 mesh & 6.90 & 1.20 \\
\hline & & & & 40 mesh & 6.00 & 1.39 \\
\hline & & & & 60 mesh & 4.90 & 1.50 \\
\hline & \multirow[t]{3}{*}{5} & \multirow[t]{3}{*}{4,580} & \multirow[t]{3}{*}{1.20} & 20 mesh & 6.00 & 1.03 \\
\hline & & & & 40 mesh & 5.10 & 1.02 \\
\hline & & & & 60 mesh & 3.60 & 1.03 \\
\hline \multirow{6}{*}{30} & \multirow[t]{3}{*}{1} & \multirow[t]{3}{*}{ n.a } & \multirow[t]{3}{*}{1.20} & 20 mesh & 7.40 & 1.10 \\
\hline & & & & 40 mesh & 4.20 & 1.13 \\
\hline & & & & 60 mesh & 4.10 & 1.20 \\
\hline & \multirow[t]{3}{*}{5} & \multirow[t]{3}{*}{4,600} & \multirow[t]{3}{*}{1.24} & 20 mesh & 8.00 & 1.20 \\
\hline & & & & 40 mesh & 7.20 & 1.20 \\
\hline & & & & 60 mesh & 6.20 & 1.25 \\
\hline
\end{tabular}

With the goal to lower the ash content level in the biopellet produced from the wastes of oil palm plantation and processing, efforts to extend the pre-treatment processes to include chemical treatment have been delivered. Since ash content is believed to be resulting from the inorganic substances contained in the feedstock such as in form of minerals, a research performed by Diputra, et al. [15] attempted to perform a demineralization process through leaching using sulfuric acid of different concentrations as a pre-treatment of OPT.

In this research, the OPT feedstock used for pellet production is varied by its bark composition, which are $0 \%, 10 \%$ and $30 \%$ of the total pellet weight, similar to the research by Wistara discussed in subchapter 2.2. The analysis of biopellet characteristics was performed on the moisture content, ash content, density and calorific value according to DIN EN 14961-2 and 51731. Scanning Electron Microscopy (SEM) was also conducted to analyse the particles bonding in the pellet, showing that both the particle interlocking (indicating high durability) and non-interlocking (indicating low durability) were found in the resulting pellet. The analysis results of the pellets produced from acid pre-treated OPT are summarized in Table 6.

The analysis results of the biopellet made from acid pre-treated OPT through leaching using sulphuric acid (H2SO4) show that all variations used in this research provided satisfactory biopellet quality that is fulfilling requirements set by SNI 8021:2014 (Table 1), DIN EN 14961-2 and 51731. The control pellet used in this research had an ash content of $2.2-3.31 \%$, which showed that the demineralization performed by means of acid pretreatment has effectively reduced the ash content of biopellet to be lower than $1.5 \%$, while still maintaining the calorific value above $4,000 \mathrm{cal} / \mathrm{g}$

\subsection{Biopellet Production with Base Pretreatment}

Since a pre-treatment using acid has shown a positive impact on the biopellet quality, especially in reducing the ash content so that the produced pellet can meet the required maximum ash content of $1.5 \%$, other researches tried to explore the potential to improve biopellet quality through base pre-treatment.

A research conducted by Agatha in 2019, used base pre-treated empty fruit bunches (EFB) to produce biopellet [16]. The alkaline used to pre-treat the EFB was sodium hydroxide $(\mathrm{NaOH})$ in three concentration variations $(3 \%, 5 \%$ and $7 \%-\mathrm{w} / \mathrm{v})$ with 2 variations of soaking duration. The amount of tapioca starch used as binder is also varied between $10 \%$ and $15 \%$ of total pellet weight. The analyses of biomass pellets characteristic were performed to observe the density, compressive strength, moisture content, ash content, volatile matter, fixed carbon, and calorific value. The results are summarized in Table 7 
Table 7 Biopellet characteristics made from base pre-treated EFB and OPM [16,17]

\begin{tabular}{|c|c|c|c|c|c|c|c|c|c|}
\hline $\begin{array}{l}\text { Pretreatment } \\
\text { method }\end{array}$ & & riations & $\begin{array}{l}\mathbf{M c}_{\mathrm{c}} \\
(\%)\end{array}$ & $\begin{array}{c}A_{c} \\
(\%)\end{array}$ & $\begin{array}{c}\text { Volatile } \\
\text { matter } \\
(\%)\end{array}$ & $\begin{array}{c}\text { Fixed C } \\
(\%)\end{array}$ & $\begin{array}{c}\text { Compressive } \\
\text { strength } \\
\left(\mathrm{kg} / \mathrm{cm}^{2}\right) \\
\end{array}$ & $\begin{array}{c}\text { Cal. } \\
\text { Value } \\
\text { (cal/g) } \\
\end{array}$ & $\begin{array}{c}\text { Cal. } \\
\text { Value } \\
\text { (MJ/kg) }\end{array}$ \\
\hline \multirow{8}{*}{$\begin{array}{l}\text { Base- } \\
\text { pretreatment } \\
\text { of EFB [16] }\end{array}$} & \multirow{4}{*}{$\begin{array}{l}10 \% \\
\text { binder }\end{array}$} & $0 \% \mathrm{NaOH}$ & 3.47 & 4.19 & 72.18 & 20.15 & 2.20 & 4,134 & 17.30 \\
\hline & & $3 \% \mathrm{NaOH}$ & 3.80 & 4.16 & 70.27 & 21.78 & 2.18 & 4,204 & 17.59 \\
\hline & & $5 \% \mathrm{NaOH}$ & 3.89 & 4.10 & 69.05 & 23.29 & 1.95 & 4,271 & 17.87 \\
\hline & & $7 \% \mathrm{NaOH}$ & 4.20 & 4.09 & 67.51 & 24.02 & 1.88 & 4,286 & 17.93 \\
\hline & \multirow{4}{*}{$\begin{array}{l}15 \% \\
\text { binder }\end{array}$} & $0 \% \mathrm{NaOH}$ & 3.60 & 4.20 & 72.79 & 19.42 & 2.21 & 4,127 & 17.27 \\
\hline & & $3 \% \mathrm{NaOH}$ & 3.85 & 4.16 & 70.81 & 21.18 & 2.19 & 4,200 & 17.57 \\
\hline & & $5 \% \mathrm{NaOH}$ & 4.10 & 4.12 & 69.40 & 22.38 & 1.98 & 4,244 & 17.76 \\
\hline & & $7 \% \mathrm{NaOH}$ & 4.09 & 4.12 & 69.08 & 22.56 & 1.89 & 4,272 & 17.87 \\
\hline \multirow{4}{*}{$\begin{array}{l}\text { Base- } \\
\text { pretreatment } \\
\text { of OPM [17] }\end{array}$} & \multicolumn{2}{|c|}{$0 \% \mathrm{NaOH}$} & 0.15 & 4.15 & 80.12 & 16.51 & 215.20 & 4,980 & 20.84 \\
\hline & \multicolumn{2}{|c|}{$15 \% \mathrm{NaOH}$} & 0.24 & 2.49 & 80.48 & 17.23 & 495.33 & 4,680 & 19.58 \\
\hline & \multicolumn{2}{|c|}{$20 \% \mathrm{NaOH}$} & 0.21 & 1.97 & 80.08 & 16.99 & 352.67 & 4,760 & 19.92 \\
\hline & \multicolumn{2}{|c|}{$25 \% \mathrm{NaOH}$} & 0.20 & 1.53 & 79.66 & 16.03 & 175.67 & 4,820 & 20.17 \\
\hline
\end{tabular}

The result shows an overall satisfactory quality of biopellets produced from base pretreated oil palm EFB, except for the ash content, which is still higher than $1.5 \%$. The base pre-treatment using $\mathrm{NaOH}$ has only slightly reduced the ash content level as well as the calorific value. The compressive strength is however decreased with the increasing concentration of $\mathrm{NaOH}$ used for pretreatment. This can be suspected to happen since the based pre-treatment can reduce the lignin composition in the EFB, while the presence of lignin helps with the particle bonding contributing to strength and durability. The amount of binder added in variation of 10 and $15 \%$ of pellet weight showed no considerable difference on all observed parameters.

A similar base pretreatment has also been performed on another type of biopellet feedstock, which is the oil palm mesocarp (OPM) [17]. Oil palm mesocarp is a waste obtained from the milling process and is also usually called the oil palm fibre (OPF) and oil palm mesocarp fibre (OPMF). The compositions of OPM are to some extent different from those of EFB, hence it came to the interest to observe whether the base pre-treatment would show similar impact when performed on different types of wastes.

The experiments were performed through multiple stages consisting of both physical and chemical treatments. Physical treatments included grinding, drying, mixing and pelletizing, whereas the chemical pretreatment was the alkalization using $\mathrm{NaOH}$ in different concentration $(15 \%, 20 \%$ and $25 \%$-w/v) with the purpose to reduce the ash content of the produced biopellet. The binder used for pellet manufacturing was tapioca. The analysis results of the biopellet quality are summarized in Table 7.

The results in Table 7 also show that the addition of base pretreatment on OPM, contrasting to that on EFB, has an observable impact on the reduction of ash content of the resulting biopellet. With a pre-treatment using $25 \%$ the ash content has been reduced to $1.53 \%$ which is almost meeting the required standard. However, at this concentration of $\mathrm{NaOH}$, the compressive strength of the pellet was decreased quite significantly. This could also be happening due the similar reason, that base pretreatment decomposed the lignin contained in OPM, so that it affected the particle bonding in the pellet. The calorific values of the OPM pellet are overall very satisfactory, and the base pretreatment does not seem to have an observable impact on this parameter.

\subsection{Biopellet Production with Torrefaction as Pretreatment}

Torrefaction is a thermal chemical process taking place at a temperature between $200-300^{\circ} \mathrm{C}$ in the absence of oxygen at around atmospheric pressure. The process runs at a low heating rate $\left(<50^{\circ} \mathrm{C} / \mathrm{min}\right)$ and decomposes parts of biomass to produce various types of volatiles. Through the torrefaction method, biomass will lose mostly the oxygen and hydrogen it contains, this includes among others water, organic substances, and gases such as $\mathrm{CO} 2$ and $\mathrm{CO}$. The removal of these substances will increase the calorific value of the biomass, previously reported from 17-19 MJ/kg to $19-23 \mathrm{MJ} / \mathrm{kg}$ [18].

Even though many of the previously discussed methods of pre-treatments have successfully produced oil palm based-biopellet with the calorific values above the required value $(>4,000 \mathrm{cal} / \mathrm{g} \approx 16.736 \mathrm{MJ} / \mathrm{kg})$, it is still very important to as much as possible increase this value, since the calorific value is very crucial for the biopellet's further application as a fuel and can improve its energy recovery potential. Hence, in this part several research that have applied torrefaction on oil palm wastes as a pretreatment in the biopellet manufacturing process are discussed. 
Table 8 Characteristics of biopellet produced from torrefied EFB and OPS [19,20]

\begin{tabular}{|c|c|c|c|c|c|c|c|}
\hline $\begin{array}{c}\text { Pretreatment } \\
\text { method }\end{array}$ & Variations & $\mathbf{M}_{c}(\%)$ & $\mathbf{A c}_{\mathrm{c}}(\%)$ & $\begin{array}{c}\text { Cal. Value } \\
\text { (cal/g) }\end{array}$ & $\begin{array}{c}\text { Cal. Value } \\
\text { (MJ/kg) }\end{array}$ & $\begin{array}{c}\text { Hemicellulose } \\
(\%)\end{array}$ & $\begin{array}{c}\text { Lignin } \\
(\%)\end{array}$ \\
\hline \multirow{2}{*}{$\begin{array}{l}\text { Torrefaction } \\
\text { of OPS as } \\
\text { biopellet } \\
\text { feedstock [19] }\end{array}$} & $\begin{array}{l}\text { Without } \\
\text { torrefaction }\end{array}$ & $\begin{array}{c}0.30- \\
0.78\end{array}$ & $\begin{array}{c}2.75- \\
2.95\end{array}$ & 4,659 & 19.51 & $20.62-21.21$ & $\begin{array}{c}30.66- \\
31.67\end{array}$ \\
\hline & With Torrefaction & $\begin{array}{l}7.10- \\
7.78\end{array}$ & $\begin{array}{c}4.42- \\
5.82\end{array}$ & 6,052 & 25.34 & $28.31-29.20$ & $\begin{array}{c}37.23- \\
38.04\end{array}$ \\
\hline \multirow{4}{*}{$\begin{array}{l}\text { Torrefaction } \\
\text { of EFB pellet } \\
\text { with speed } \\
\text { variation [20] }\end{array}$} & $\begin{array}{l}\text { Without } \\
\text { torrefaction }\end{array}$ & 7.96 & 12.36 & 3,781 & 15.82 & n.a. & n.a. \\
\hline & $\begin{array}{l}\text { With Torrefaction } \\
16 \mathrm{rpm}\end{array}$ & 0.52 & 17.71 & 4,240 & 17.74 & n.a. & n.a. \\
\hline & $\begin{array}{l}\text { With Torrefaction } \\
31 \mathrm{rpm}\end{array}$ & 0.4 & 16.50 & 3,982 & 16.66 & n.a. & n.a. \\
\hline & $\begin{array}{l}\text { With Torrefaction } \\
37 \mathrm{rpm}\end{array}$ & 0.32 & 15.50 & 4,111 & 17.20 & n.a. & n.a. \\
\hline
\end{tabular}

A research conducted by Savitri [19] studied the effect of oil palm shell (OPS) torrefaction on the quality of biopellet manufactured from it. The observations performed in this research showed a decrease of moisture content from $7.1-7.78 \%$ to $0.3-0.78 \%$, however the ash content was increased after the treatment of torrefaction, from initially $2.75 \%-2.95 \%$ to $4.42-5.82 \%$. Meanwhile, the calorific value underwent a significant increase just as expected from the purpose of applying torrefaction, from $19.51 \mathrm{MJ} / \mathrm{kg}$ to $25.34 \mathrm{MJ} / \mathrm{kg}$. The comparison between pellet characteristics with and without torrefaction as pre-treatment is shown in Table 8.

Another research has studied the addition of torrefaction to improve biomass pellet quality made from oil palm EFB, however instead of applying it as a pretreatment, the torrefaction was added as a final step, subsequent to the pelletization [20]. The torrefaction of the pellets was done in a rotary reactor with the size of 15 $\mathrm{cm}$ long and $15 \mathrm{~cm}$ in diameter made of iron plates. The temperature of torrefaction was maintained around $240-$ $310^{\circ} \mathrm{C}$, conducted in variations of time $(20,30$ and 45 minutes) and rotational speed (16, 31 and $37 \mathrm{rpm})$.

The results in Table 8 show the characteristics comparison between untorrefied EFB pellets and those that have been torrefied using different rotational speeds. The changes in rotational speed does not significantly affect all quality parameters, except for the calorific value and ash content. The highest calorific value is found when $16 \mathrm{rpm}$ was used, however this also resulted in the highest ash content. The increase of ash content after torrefaction is believed to happen due to the reduction of volatile components in hemicellulose and cellulose, which evaporated during the torrefaction process. It has been reported on other works that the hemicellulose decomposes at temperature at around $275-280^{\circ} \mathrm{C}$. The time variation conducted in this research has shown insignificant effect on most of the relevant biopellet quality parameters, and as a conclusion the author suggested a torrefaction duration of 20 minutes to be chosen.
One additional crucial finding in this research was that the EFB pellet after torrefaction showed a change in its hygroscopic characteristic, changing from hydrophilic to hydrophobic. The hydrophobicity of a solid fuel is important to prevent fire hazard during storage, preventing biomass decomposition, as well as water adsorption during storage and transportation.

The torrefied EFB pellet in this research showed excellent durability when soaked in water. The untorrefied pellet absorbed water and broke down after 1 minute soaking duration in water, while the torrefied ones remained intact up to 3 hours soaking time and could hold in form until 24 hours soaking. This is considered to be one big advantage of adding torrefaction to the manufacturing process of biopellet.

\section{ADDITIONAL TREATMENT IN BIO- PELLET PROCESSING}

Oil palm wastes such as EFB have been shown to have a good potential to be used as biopellet feedstock. However, one of the hardest problems to be overcome with is the high ash content of the resulting pellet. This has been suspected to be caused by the inorganics and mineral content (such as potassium and silica) in the feedstock itself. Attempts have been made to reduce the ash content by various treatments, among others those that have been discussed earlier in this paper. In this part, an additional physical treatment through leaching using liquid wastes is discussed, whose purpose is to reduce the mineral content of the feedstock.

A research conducted by Ningsih [21] used tapioca wastewater for leaching of oil palm EFB with the purpose to reduce its potassium content, understanding that potassium is highly soluble in water. The variations of soaking time $(0,5,30,60,90,120 \mathrm{~min}, 12$ hours and 24 hours) and types of tapioca wastewaters (collected from tapioca mill and from biogas digester) were performed in this experiment. The use of tapioca wastewater to remove potassium is aimed at solving two problems, one is 
reducing the ash content of biopellet, and the second is to solve the environmental problem caused by abundant wastewater coming from tapioca production in Indonesia. Table 9 shows the analysis results of EFB feedstock, the wastewater coming from tapioca mill and the wastewater from biogas digester. It can be seen that the potassium content in EFB is dominant, followed by silica and chlorine.

Table 9 Minerals content of EFB and tapioca wastewater [21]

\begin{tabular}{|c|c|c|c|}
\hline \multirow{2}{*}{$\begin{array}{c}\text { Mineral } \\
\text { content }\end{array}$} & \multirow{2}{*}{$\begin{array}{c}(\%) \\
\text { in EFB }\end{array}$} & \multicolumn{2}{|c|}{$\begin{array}{l}(\mathrm{mg} / \mathrm{l}) \text { in tapioca wastewater } \\
\text { from }\end{array}$} \\
\hline & & Mill & $\begin{array}{c}\text { biogas digester } \\
\text { effluent }\end{array}$ \\
\hline $\mathrm{K}$ & 67.04 & 218 & 221.87 \\
\hline $\mathrm{Si}$ & 8.87 & - & - \\
\hline $\mathrm{Mg}$ & 3.01 & - & 0.82 \\
\hline $\mathrm{Cl}$ & 8.53 & - & - \\
\hline $\mathrm{Ca}$ & 6.63 & - & 1.48 \\
\hline $\mathrm{P}$ & 2.01 & - & 120 \\
\hline $\mathrm{Mc}$ & 8.2 & n.a. & n.a. \\
\hline Ac & 5.97 & n.a. & n.a. \\
\hline
\end{tabular}

The ash content of EFB after leaching using 2 types of wastewater was reported to be significantly reduced. The soaking of EFB in tapioca mill wastewater for 5 minutes decreased the ash content drastically from $5.97 \%$ to $1.8 \%$, while soaking for the same duration in biogas effluent reduced it to $2.3 \%$. A longer period of soaking time decreased the ash content further, and with 30 minutes soaking in tapioca mill wastewater, the ash content was reduced to $1.13 \%$. However, soaking longer than this, namely 60 minutes to 24 hours has been observed to slightly increase the ash content again. This phenomenon happened on both types of wastewaters used.

A similar attempt has been performed by using tofu wastewater instead of tapioca wastewater [21]. The results reported in this research have shown an increase in calorific value (from $16.86 \mathrm{MJ} / \mathrm{kg}$ to $18.35 \mathrm{MJ} / \mathrm{kg}$ ), a decrease in potassium content (from $87.3 \%$ to $1.66 \%$ ) and a decrease in ash content (from $4.51 \%$ to $2.96 \%$ ).

Even though these researches did not directly analyse the biopellet quality, since no pelletization was performed, the results have shown that adding a leaching process on the feedstock can successfully reduce the ash content. Hence, it can be expected that when the leached EFB is further applied for biopellet manufacturing, the resulting pellet will have a satisfactory quality related to its ash content level.

\section{DISCUSSION AND CONCLUDING REMARKS}

In this paper various methods of pre-treatment that can be applied in the biopellet manufacturing process from biomass waste of oil palm plantation and mill have been discussed and compared. When it comes to obtaining satisfactory quality of biopellet, it can be seen from all the work that the biggest challenge is to achieve the ash content level and calorific value that meet standard requirements. In Indonesia, these qualities are standardized by SNI 8021:2014, setting ash content level to a maximum of $1.5 \%$ and a calorific value to a minimum of $4,000 \mathrm{cal} / \mathrm{g}$ or equal to $16.736 \mathrm{MJ} / \mathrm{kg}$.

Common physical pretreatments such as size reduction (including cutting, chopping and grinding) are not always able to achieve these requirements, so enhancement to the pretreatment has been explored. Combining oil palm waste with other types of feedstocks such as tea waste can be used to increase the calorific value of the pellet. Another way to achieve this is by using different types of binders, which can be in the form of starch (amylum), tapioca starch and PVAC, and also by variating the amount ratio between the binder and the feedstock. Aditya suggested that when using tapioca or PVAC, the best ratio to obtain the highest calorific value to be used is 10:90 between binder to EFB by weight [10]. The size of the feedstock was also found to have an impact on the biopellet calorific value, as observed in the work of Falah and Nelza [11]. However, those methods could not reduce the ash content nearing the requested value.

Reducing ash content is very important for the main reason of its negative effect on heating equipment, such as boilers and heat exchangers. High ash content level can cause deposit on the surface of the equipment, slagging in furnaces and can also cause corrosion [21]. Reducing ash content in biopellet made from oil palm wastes apparently requires more effort than achieving other qualities.

Changing the temperature of densification was found to be giving a significant effect in reducing ash content, however still not giving the required value. One research has succeeded in both lowering ash content and increasing calorific value, which however required the mixing of oil palm wastes with laban wood charcoal [14]. Any other physical pre-treatments discussed in this paper failed to give meaningful reduction of biopellet ash content. Hence, the literature study advanced to the involvement of chemical pre-treatment in the manufacturing process.

The chemical treatments discussed here were acid pretreatment using sulphuric acid (H2SO4), base pretreatment using sodium hydroxide $(\mathrm{NaOH})$ and thermal-chemical reaction through torrefaction in the absence of oxygen. The acid pretreatment showed very satisfactory results with ash content of biopellets around and even lower than $1.5 \%$, while maintaining the calorific value above $4,000 \mathrm{cal} / \mathrm{g}$. The base pretreatment did not show a very meaningful decrease in ash content and increase in calorific value, even though it improved 
the overall quality of the pellet. Torrefaction on the other hand improved the calorific value very significantly, however failed to achieve low ash content, it even went higher. Furthermore, leaching using water can be applied as an additional pre-treatment of biomass pellet feedstock, since it has been proven that this can reduce ash content of the feedstock to a certain point.

In conclusion, the acid pretreatment is by far the most successful pretreatment, among others. However, the study discussed was only observing the effect of acid pretreatment on OPT, and for the application on other types of oil palm wastes, further validation needs to be performed. Moreover, a combination between various pretreatment methods can have potential to be explored, in example combining the acid pre-treatment with a torrefaction, by using a binder of optimum type and amount ratio. When all the quality parameters have been met, the commercial utilization of oil palm waste-based biopellet can be developed and will overcome both the national renewable energy demand problem and environmental issue.

\section{REFERENCES}

[1] Petroleum B. Statistical Review of World Energy 2020. Statistical review of world energy. 2020 Jun;65. Petroleum, B., 2020. 69 th $^{\text {Edition. }}$

[2] Dogaojo, J. Biomass in Indonesia's energy mix. Enlit Asia. 2020.

[3] IESR. Indonesia Energy Transition Outlook 2021: Tracking Progress of Energy Transition in Indonesia. Jakarta: Institute for Essential Services Reform (IESR). 2021.

[4] Dungani R, Aditiawati P, Aprilia S, Yuniarti K, Karliati T, Suwandhi I, Sumardi I. Biomaterial from oil palm waste: properties, characterization and applications. Palm Oil. 2018 Jul 18;31.

[5] Hambali E, Rivai M. The potential of palm oil waste biomass in Indonesia in 2020 and 2030. InIOP Conference Series: Earth and Environmental Science 2017 May 1 (Vol. 65, No. 1, p. 012050). IOP Publishing.

[6] Munawar SS, Subiyanto B. Characterization of biomass pellet made from solid waste oil palm industry. Procedia Environmental Sciences. 2014 Jan 1;20:336-41.

[7] Brunerová A, Müller M, Šleger V, Ambarita H, Valášek P. Bio-pellet fuel from oil palm empty fruit bunches (EFB): Using European standards for quality testing. Sustainability. 2018 Dec;10(12):4443.

[8] Pua FL, Subari MS, Ean LW, Krishnan SG. Characterization of biomass fuel pellets made from
Malaysia tea waste and oil palm empty fruit bunch. Materials Today: Proceedings. 2020 Jan 1;31:18790.

[9] Nagaraja M, Charles I, Sundaresan R, Natarajan R, Srinivas T. Energy and byproducts recovery from tea waste. Int. J. Electr. Energy. 2013;1:49-54.

[10] Aditya RF. Biomass Pellets from Oil Palm Empty Fruit Bunches (OP-EFB). ICONIET PROCEEDING. 2018;2(1):65-8.

[11] Falah M, Nelza N. Pembuatan biopelet dari limbah tandan kosong kelapa sawit (tkks) sebagai bahan bakar terbarukan. Ready Star. 2019 Nov 29;2(1):905 .

[12] Wistara NJ, Rohmatullah MA, Febrianto F, Pari G, Lee SH, Kim NH. Effect of bark content and densification temperature on the properties of oil palm trunk-based pellets. Journal of the Korean Wood Science and Technology. 2017;45(6):671-81.

[13] Zulfian FD, Setyawati D, Nurhaida RE. Kualitas biopelet dari limbah batang kelapa sawit pada berbagai ukuran serbuk dan jenis perekat. Jurnal hutan lestari. 2015;3(2):208-16.

[14] Lamanda DD, Setyawati D, Diba F, Roslinda E. Karakteristik Biopelet Berdasarkan Komposisi Serbuk Batang Kelapa Sawit Dan Arang Kayu Laban Dengan Jenis Perekat Sebagai Bahan Bakar Alternatif Terbarukan. JURNAL HUTAN LESTARI. 2015;3(2).

[15] Diputra P. Biopelet batang kelapa sawit sebagai Energi Alternatif Terbarukan dengan Pre-treatment Demineralisasi. 2017. Bachelor Thesis IPB University.

[16] Agatha, F. Application of empty fruit bunch waste for biomass pellets with chemical pre-treatment (efb). 2019. Swiss German University.

[17] Zubaidah, D. A. Utilization of oil palm mesocarp (opm) as raw material of biopelet as energy source. 2019. Swiss German University.

[18] Bergman PC, Kiel JH. Torrefaction for biomass upgrading. InProc. 14th European Biomass Conference, Paris, France 2005 Oct 17 (Vol. 2005, pp. 17-21). sn.

[19] Savitri, E.A. pengaruh ukuran bahan baku erhadap kinerja torefaksi cangkang sawit. 2020. Universitas Lampung.

[20] Haryanto A, Nita R, Telaumbanua M, Suharyatun S, Hasanudin U, Hidayat W, Iryani DA, Triyono S, Wisnu FK. Torréfaction to improve biomass pellet made of oil palm empty fruit bunch. InIOP Conference Series: Earth and Environmental 
Science 2021 May 1 (Vol. 749, No. 1, p. 012047). IOP Publishing.

[21] Rohmah, N. Pemanfaatan air limbah tahu untuk menurunkan kadar kalium pada tandan kosong kelapa sawit (tkks) dengan proses pencucian (leaching). 2019. Universitas Lampung. 